Egyptian Journal of Rabbit Science, 25(1): 59 - 81(2015)

\title{
DIETARY EXPOSURE EFFECT OF SUBLETHAL DOSES OF METHOMYL ON GROWTH PERFORMANCE AND BIOCHEMICAL CHANGES IN RABBITS AND THE PROTECTIVE ROLE OF VITAMIN E PLUS SELENIUM
}

\author{
El-Sayed A. El-Sheikh ${ }^{1}$ Khalid M. Mahrose ${ }^{2 *}$ and Ismail E. Ismail ${ }^{2}$ \\ ${ }^{1}$ Plant Protection Department, Faculty of Agriculture, Zagazig University, \\ Zagazig 44511, Egypt. \\ ${ }^{2}$ Poultry Department, Faculty of Agriculture, Zagazig University, Zagazig \\ 44511, Egypt.*Email: ostrichkhalid@zu.edu.eg
}

The current study aimed to investigate the adverse effects of methomyl (Met) dose at different time intervals alone or with weekly Vitamin E+Selenium (ESe) injection on growth performance, blood biochemical parameters, and liver \& kidney histopathological changes of New Zealand White (NZW) growing male rabbits. Five groups of 10 weaned rabbits (at 7 weeks of age and average initial live body weight of $824.40 \pm 71.0 \mathrm{~g}$ )were randomly assignedand used. The first group was served as control, the $2^{\text {nd }}$ and $3^{\text {rd }}$ groups were received a daily dose of 10 and $20 \mathrm{mg} \mathrm{kg}^{-1}$ body weight $(\mathrm{BW})$ of Met, while, the $4^{\text {th }}$ and $5^{\text {th }}$ groups were received a daily dose of 10 and $20.0 \mathrm{mg} \mathrm{kg}^{-1} \mathrm{BW}$ of Met with weekly subcutaneously ESe injection.

Results of the present study showed that: growth performance did not change significantly throughout experimental periods. Continuous exposure to Met alone or with ESe injection at 28 days showed a significant $(P \leq 0.05$ and 0.01$)$ decrease in RBCs count. WBCs was increased significantly $(P \leq 0.01)$ with exposure to Met only at 35 days. A significant decrease in total protein, urea, aspartate aminotransferase (AST) and alkaline phosphatase (ALP) due to exposure to Met was obtained. However, Alanine aminotrans ferase (ALT) and creatinine were increased significantly at 14 and 35 days. Degenerative changes and edematous fluid in the portal area with necrotic changes in hepatic cells were observed due to Met effect. However, a few of proliferation of bile duct with edematous fluid in the portal area were affected of Met dose with ESe injection. Kidney damage due to Met exposure was involve ingrenal tissue damage with 
leukocyte infiltration, and degenerative changes due to Met exposure and ESe injection. Dietary Met administration with or without injection of ESe did not significantly affect most of carcass traits studied, except for heart, spleen, lung and fore limb percentages, which were significantly $(P \leq 0.05)$ differed.

In conclusion, the overall findings showed that Met exposure can cause biochemical changes, hepatic and renal damage to rabbits with low protection role of ESein NZW growing male rabbits.

Keywords: Rabbits, methomyl, growth performance, blood parameters, histopathology, carcass traits, vitamin E plus selenium.

Rabbit farming has significant potential and useful contribution in improving meat supply, food security and national economy in developing countries (Anjana and Goswami, 2012, Ebeid et al., 2012 and Ebeid et al., 2013). Although there is an increasing interest in ventures ofraising rabbits with different sizes in Egypt, several difficulties and constraints stand against the successfulness of these enterprises. Among these difficulties, the environmental and nutritional factors are important which affect the intensive economic production of rabbits under the sub-tropical conditions in Egypt (Mahrose et al., 2010).

Farmers use synthetic insecticides to save their crops from pest attack and to increase the per acre yield of various commodities. Insecticides contamination resulting from agricultural pest control practices is limiting the safe use of these compounds. A carbamate insecticide group is one of the widely used groups for control a variety of pest insects through contact or stomach poison on different agricultural crops. The toxicity of this group to insects and mammals is determined by a number of factors that may affect the insecticides as they are absorbed, trans located and inactivate the target site, leading to poisoning (Fukuto, 1990). Clinical and subclinical changes are the major effects of this group. Some of these insecticides are highly toxic for mammals (El-Shenawy et al., 2009).

Methomyl (Met) compound is introduced by Dupont in 1966 which is functionally analogous to organophosphates for inhibiting enzyme activity of acetyl cholinesterase in mammals and insects (Baron, 1991; Mohammad et al., 2007). Met is the most toxic pesticide which enter water supplies from agricultural runoff, accidental pills or faulty waste disposal techniques (Marai et al., 2010). Met is a commonly used carbamate insecticide in agriculture 
(WHO, 1996) to control a wide range of insect species including lepidoptera, homoptera, aphids and mites that attack a variety of vegetables, field crops, and certain fruit trees (Baron, 1991) through direct contact and ingestion (WHO, 1996). A contact and systemic insecticide, Met, possesses high-acute toxicity to mammals with oral $\mathrm{LD}_{50}$ of $30-34 \mathrm{mg} / \mathrm{kg}$ in rats, and dermal $\mathrm{LD}_{50}$ of $>5 \mathrm{~g} / \mathrm{kg}$ in rabbits (WHO, 1996), which is classified as a highly hazardous compound by the World Health Organization.Previous researches revealed that methomyl induced hematological and biochemical alterations in rat (Garg et al., 2009; El-Demerdash et al., 2013), reproductive toxicity in rats (Shalaby et al., 2010), and cytotoxicity in insect cell lines (Guanggang et al., 2013)

Vitamin $\mathrm{E}$ is essential for growth, immune function enhancement, tissue integrity, reproduction, disease prevention and antioxidant function in biological systems (Rooke et al., 2004; Dalle Zotte and Szendro, 2011; Ebeid et al., 2013). Selenium (Se) is an essential element required for normal animal growth (Suraï, 2002).

Therefore, the aim of the present study was to investigate the adverse effects of Met on the performance of growing rabbits, biochemical and histological parameters, as well as carcass traits and the possible protective role of vitamin E plus Selenium (ESe).

\section{MATERIALS AND METHODS}

\section{Chemicals and Reagents}

Methomyl (Met), a common name of the commercial formulation named Neomyl ${ }^{\circledR}$ 90\% SP, was purchased from Kafr El-Zayat for Pesticides and Chemical Company, Kafr El-Zayat City, Egypt. Vitamin E plus Selenium; commercially known as Vitasellen ${ }^{\circledR}$ (Adwia pharmaceuticals Co., Egypt), where each $100 \mathrm{ml}$ contained; $15 \mathrm{~g}$ of vitamin E acetate and $0.167 \mathrm{~g}$ sodium selenite. All kits of biochemical studies were purchased from Diamond Diagnostic (Heliopolis, Cairo, Egypt) except for ALP which purchased from Teco-Diagnostics (Anaheim, CA). All other chemicals used in this study were of technical grade with the highest purity available.

\section{Animals and Experimental Design}

Fifty weaned males of New Zealand White (NZW) rabbits at 7 weeks of age and average initial live body weight of $824.40 \pm 71.0 \mathrm{~g}$ were purchased from Rabbitry of Faculty of Agriculture, Zagazig University, and used in the present study. Rabbits were individually housed in galvanized wire cages until 
the end of the experimental period of 11 weeks of age. Rabbits were reared in well-ventilated farm conditions of $25 \pm 2^{\circ} \mathrm{C}, 50-60 \%$ relative humidity, and 12:12 hr. light-dark cycle. All rabbits were fed on pelletized feed ad libitum. The basal diet consisted of $28 \%$ alfalfa hay, $18 \%$ barley, $18 \%$ soybean meal (44\% crude protein), $25 \%$ wheat bran, $6 \%$ yellow corn, $3 \%$ molasses, $1.1 \%$ limestone, $0.3 \%$ sodium chloride, and $0.6 \%$ vitamin and mineral premix. The basal diet contained of $18.18 \%$ crude protein, $13.43 \%$ crude fiber, $2.29 \%$ ether extract, 2656 digestible energy (Kcal/ $/ \mathrm{kg})$. The diet was formulated according to NRC (1977).All rabbits were kept under the same managerial, hygienic and environmental conditions. Fresh water was automatically available all the time through stainless steel nipples fixed in each cage which equipped with feeders. Groups of rabbit exposed to Met (with or without ESe injection) showed no mortality during experimental period.

For experimental design, rabbits were randomly divided into five groups, in completely simple randomized design, with 10 rabbits/each group. The first group received daily untreated pelleted diet and served as control. The second and third groups received a daily dose of $10 \mathrm{mg} \mathrm{kg}^{-1}$ body weight (BW) (equal to $75 \mathrm{ppm}$ according to the amount of the diet supplied daily to each animal) and $20 \mathrm{mg} \mathrm{kg}^{-1} \mathrm{BW}$ (equal to $150 \mathrm{ppm}$ according to the amount of the diet supplied daily to each animal) of Met, respectively. The fourth and fifth groups received a daily dose of $10 \mathrm{mg} \mathrm{kg}^{-1} \mathrm{BW}$ and $20.0 \mathrm{mg} \mathrm{kg}^{-1} \mathrm{BW}$ of Met with weekly subcutaneously injection of $0.5 \mathrm{ml}$ of ESe, which showed no toxicity according to Lebas (2000). Doses of Met were prepared by completely mixing insecticide solutions with the diet amount offered daily to each animal individually in a rate of 1:10 (insecticide solution volume: diet weight) to give the daily doses of $10 \mathrm{mg} \mathrm{kg}^{-1} \mathrm{BW}$ or $20.0 \mathrm{mg} \mathrm{kg}^{-1} \mathrm{BW}$. Supplemented doses were adjusted weekly according to the changes in the body weight. Experimental design was approved by the Local Committee, and the protocol conforms to the guidelines of the National Institutes of Health (NIH).

\section{Growth performance measurements}

Live body weight was recorded for each rabbit at 6,8 and 11 weeks of the age, then weight gain was calculated. Feed consumption was determined and calculated as gram diet per rabbit per day during the periods of 6-8, 8-11 and 6-11 weeks of age. Feed consumption was monitored daily and the remaining diet from each animal was determined and taken into consideration when calculating the feed conversion ( $\mathrm{g}$ feed/g gain). 
DIETARY EXPOSURE EFFECT OF SUBLETHAL DOSES OF METHOMYL ON RABBITS 63

\section{Slaughtering and carcass traits}

At the end of the experimental period (35 days of the experiment period; 12 weeks of the age), three rabbits from each group were randomly taken, fasted for 12 hours and slaughtered (Lukefahr et al., 1992). After complete bleeding, pelt, viscera's and tail were removed; the percentages of carcass weight, giblets weights (liver, kidneys and heart weight), spleen weight and weights of fore limb, middle part and hind limb were calculated as relatives to slaughter weight.

\section{Collection of Blood Samples}

Blood samples were collected at 14, 28 and 35 days of the experiment ( 8,10 and 11 weeks of age) from the same 3 animals of each group through ear vein. Blood samples were collected into $10 \mathrm{ml}$ EDTA tubes and gently mixed. Red blood cells (RBCs) and white blood cells (WBCs)counted directly after blood collection. Plasma was obtained by centrifugation of blood samples at $3000 \mathrm{rpm}$ for 20 minutes, then aliquots in eppendorf tubes, and stored at $-20{ }^{\circ} \mathrm{C}$ until time of biochemical analysis within 3 weeks.

\section{Blood picture}

RBCs and WBCs were counted using AO Bright line heamocytometer under light microscopy. RBCs were counted at 400 magnifications, after dilution to 200 times with physiological saline $(0.9 \%$ sodium chloride solution) before counting (Wintrobe, 1965). WBCs were counted at 100 magnifications after diluting blood samples to 20 times of original volume with a diluting fluid (1\% acetic acid solution and $1 \mathrm{mg}$ of Leishman's stain) before counting (Hepler, 1966).

\section{Determination of biochemical parameters}

Colorimetric assays were performed using either spectrophotometer (Spectronic 20, Bausch and Lomb, USA) or 96-well microplate using Microplate Autoreader, EL311S (Bio-TEK Instrument, Highland Park, Winooski, VT). Total protein concentrations in plasma were determined using a commercial available kit according to the method of Koller (1984). Levels of Glucose, urea, creatinine and activities of alanine aminotransferase (ALT), aspartate aminotransferase (AST), alkaline phosphatase (ALP) were determined using commercial available kits according to the manufacturers' protocols.

\section{Histopathological investigations}

At the end of the experiment, three males of each group (control or treated) were randomly slaughtered. Specimens of liver and kidney were 
prepared for histological investigation. After fixation in a $10 \%$ formalin saline, specimens were dehydrated, cleared, embedded in paraffin wax and sectioned at 5 microns thickness using a rotary microtome. Sections were stained by Hematoxylin and Eosin (Carleton et al., 1980).

\section{Statistical Analysis}

The obtained data were statistically analyzed in completely randomized design (Snedcor and Cochran, 1982) using SAS® Software Statistical Analysis (SAS, 1998). Differences among mean were tested by Duncan's multiple range test (Duncan, 1955).

\section{RESULTS AND DISCUSSION}

\section{Some growth performance traits}

Results of live body weight, daily body weight gain, feed consumption and feed conversion are shown in Tables 1 and 2. Data indicate that growth performance traits studied did not significantly change throughout all experimental periods. Current findings are in agreement with those obtained by Abd El-Maksoud (1998), who reported that body weight of pregnant Californian rabbits did not significantly change due to exposure to dietary Selecron. The same author showed that the final body weight at the $28^{\text {th }}$ day of gestation period was lower than the initial one with no differences in the average of daily feed consumption, although it was insignificantly decreased in the groups had doses of Selecron.

\section{Hematological analysis}

Data in Table 3 showed a significant decrease $(\mathrm{P} \leq 0.01)$ in $\mathrm{RBCs}$ count of rabbits' blood after 28 days of treatment in all groups treated with Met alone or Metwith weekly ESe injection. However, after 35 days of treatment, non-significant changes were observed with all treatments except in the group treated with $10 \mathrm{mg} \mathrm{Met} \mathrm{kg}^{-1} \mathrm{BW}$ with ESe injection. WBCs showed non-significant changes in rabbit groups treated with Met alone or Met and injected with ESe after 14 and 28 days. A significant increase $(\mathrm{P} \leq 0.01)$ was recorded in WBCs of rabbits treated with $10,20 \mathrm{mg} \mathrm{kg}^{-1} \mathrm{BW}$ and $10 \mathrm{mg} \mathrm{kg}^{-1}$ BW of Met plus weekly ESe injection at 35 days, when compared with the control group.

WBCs significantly increased $(\mathrm{P} \leq 0.01)$ in the group of rabbits exposed to $20 \mathrm{mg} \mathrm{kg}^{-1} \mathrm{BW}$ Met only compared with the group treated with the same 
DIETARY EXPOSURE EFFECT OF SUBLETHAL DOSES OF METHOMYL ON RABBITS 65 
DIETARY EXPOSURE EFFECT OF SUBLETHAL DOSES OF METHOMYL ON RABBITS 67 
dose plus weekly ESe injection, and the latter groupdid not significantly change with control group after 28 and 35 days (Table 3).

The continuous exposure of rabbits to Met induced hematological alterations. RBCs count was significantly decreased after 28 days of exposure, where, the injection of ESe didn't alter the insecticide effect. However, WBCs was significantly increased after 35 days of exposure with a protection role of ESe with the highest dose tested of Met. Rabbits' hematology changes as affected by dietary Met exposure agree with Mossa and Abbassy (2012) who showed a decrease in RBCs count in rats due to treatment with chlorpyrifos-methyl or rats treated with diazinon (El-Sheikh et $a l ., 2008)$. On the other hand,WBCs count was significantly increased due to the exposure of Wister rats to Met vitamin E supplementation (Garg et al. 2009)which confirm the current findings. The change in hematology resulted from continuous exposure to Met may be due to an increase rate of breakdown of red blood cells. Although Met is not known as antigenic in nature, the increase in WBCs is indicative of stimulation of bone marrow (Garg et al., 2009). The increase of WBCs may be due to the activation of animals defense mechanisms and immune system (Mossa and Abbassy, 2012), and the increase in neutrophils counts, which is the first line of defense against infections, tissue injury, parasite attack and inflammatory response against foreign materials (Jain 1988). The elevation in the lymphocytes could be attributed to adaptation of the animal to long term toxic responses and the important role of lymphocytes in antigen-antibody reaction (Garg et al., 2009).

\section{Biochemical parameters}

Table 4 shows levels of total protein, glucose, urea and creatinine groups of rabbits due to exposure to Met alone or weekly injection with ESe for 14, 28 and 35 days. Plasma total protein content was increased significantly $(\mathrm{P} \leq 0.01)$ after 14 days of exposure in all groups compared with the untreated group. While, the increase turned to a significant decrease $(\mathrm{P} \leq 0.01)$ in all groups after 28 and 35 days of treatment. There were no significant changes in plasma glucose level after exposure to Met only or Met with ESe injection at 14, 28 and 35 days, except in the group treated with 20 $\mathrm{mg} \mathrm{kg}{ }^{-1} \mathrm{BW}$ for 35 days, which showed a significant decrease $(\mathrm{P} \leq 0.05)$ compared with the control. Urea level was decreased significantly $(\mathrm{P} \leq 0.01)$ in groups treated with Met and ESe at 14 and 28 days, in addition to the group treated with $10 \mathrm{mg} \mathrm{kg}^{-1} \mathrm{BW}$ of Metat 28 days compared with the control group. Plasma creatinine level was increased significantly $(\mathrm{P} \leq 0.01)$ 
DIETARY EXPOSURE EFFECT OF SUBLETHAL DOSES OF METHOMYL ON RABBITS 69 
at14 days when rabbits treated with Met and ESe, except in the group of rabbits treated with $10 \mathrm{mg} \mathrm{kg}^{-1} \mathrm{BW}$ of Met only at 35 days which showed non-significant changes compared with the control group.

The injection of ESe to rabbits treated with the Met didn't show significant changes in total protein compared with the same doses of Met only. While, a significant decrease $(\mathrm{P} \leq 0.05)$ in glucose level was noted in the group of rabbits treated with $20 \mathrm{mg} \mathrm{kg}^{-1} \mathrm{BW}$ Met withweekly ESe injection compared with the same dose only. Injection of ESe in the group of rabbits treated with $10 \mathrm{mg} \mathrm{kg}^{-1} \mathrm{BW}$ significantly decreased $(\mathrm{P} \leq 0.01)$ urea level at 14 days of treatment compared with the same dose of Met only. A significant increase $(\mathrm{P} \leq 0.01)$ was noted in creatinine concentration in the group treated with $20 \mathrm{mg} \mathrm{kg}^{-1} \mathrm{BW}$ and injected with ESe at 14 and 35 days of treatment as compared with the same dose of Met only (Table 4).

Chemistry panels including several enzyme tests have been performed to rule out organ malfunction and used to diagnose and monitor a variety of disorders (Bioshop et al., 2000).Different insecticides caused a decrease in total protein concentration (Khan et al., 2003; Mossa et al., 2011), and this effect may be due to the imbalance between the rate of protein synthesis and the rate of degradation (El-Demerdash and Nasr, 2014). The increase in blood glucose of rabbits treated with Met only may indicate disrupted carbohydrate metabolism due to enhanced breakdown of liver glycogen, possibly mediated by an increase in adrenocorticotrophic and glucagon hormones and/or reduced insulin activity (Raja et al., 1992). The ESe supplementation almost normalized glucose level with $10 \mathrm{mg} \mathrm{kg}^{-1} \mathrm{BW}$ Met exposure, however, decreased the level of glucose with high dose of Met.

The present results showed that urea and creatinine levels in rabbit's plasma was increased due to continuous exposure to Met (Table 4). These results agree with those of the other findings when tested Met on different organisms such as rats (Fayez and Bahig, 1991), workers (Khan et al., 2008), and mice (El-Demerdash et al., 2013). The increase in urea and creatinine concentrations in plasma of rabbits treated with Met in the current study can be attributed to its effect on liver function (Table 4), as urea is the endproduct of protein catabolism and/or referred to kidney dysfunction and diseases (Tanner, 2012). The increase in plasma creatinine and urea indicate the leak of kidney ability to filter the waste products from the blood and excrete them in the urine (El-Demerdash et al., 2013) as it supplied with a high blood volume due to its susceptibility to toxicants found in the environment. 
The activity of ALT was significantly increased $(\mathrm{P} \leq 0.01)$ only in the group treated with $20 \mathrm{mg} \mathrm{kg}^{-1} \mathrm{BW}$ at 14 days of treatment (Table 5), while AST was significantly decreased $(\mathrm{P} \leq 0.05)$ in the same group at 28 days of treatment compared with control. ALP activity was significantly decreased $(\mathrm{P} \leq 0.01)$ in rabbits plasma in all groups treated with Met alone or Met with ESe injection at 28 days compared with the control group.

The group of rabbits treated with $10 \mathrm{mg} \mathrm{kg}^{-1} \mathrm{BW}$ of Met and injected with ESe showed markedly a decrease in ALT and AST at 14 days of treatment, while they were significantly $(\mathrm{P} \leq 0.05$ and 0.01$)$ increased in the same groups at 35 days compared to the group treated with the same dose of insecticide only. ALP was significantly $(\mathrm{P} \leq 0.05)$ decreased in the group treated with $20 \mathrm{mg} \mathrm{kg}^{-1} \mathrm{BW}$ of Met and injected weekly with ESe, compared to the group treated with the same dose only when exposed to the insecticide for 35 days (Table 5).

The treatments of rabbits with Metat 35 days indicate that ALT, AST and ALP activities were generally increased. The increase of the indicated enzymes is reflecting the injury in both liver and kidney (El-Demerdash and Nasr, 2014). Liver is responsible for detoxification processes, metabolism and biosynthesis of energetic macromolecules for different essential functions. Also, it is the first organ to face any foreign molecule that is carried through portal circulation and it is subjected to most damage. In addition, ALT and AST are important enzymes as specific indicators for liver damage and in playing a role in amino acids catabolism and biosynthesis (Harper, 1979).

\section{Histopathological investigations}

Histological examination of liver (Figure 1) showed degenerative changes in the hepatic parenchyma tissue associated with extravasation of $\mathrm{RBCs}$, edematous fluid in the portal area with necrotic changes in hepatic cells and proliferation of bile duct. The results agree with those obtained by Garba et al. (2013) who found generalized hepatic vascular congestion, milled perportal inflammation and lymphocytic infiltration in the liver of albino rats exposed to $1 \%$ dichlorvos pesticide. However, a few of proliferation of parenchyma and bile duct with normal structure of hepatic cord are the changes in liver of rabbits treated with Met and weekly injected with ESe. The changes in groups treated with Met and injected with ESe were less than those of the other groups exposed to Met alone, where the improvement in liver tissue can be attributed to ESe injection. The toxic effects of Met on kidney showednephritic damage with infiltration of 
EL-SAYED EL-SHEIKH et al. 
DIETARY EXPOSURE EFFECT OF SUBLETHAL DOSES OF METHOMYL ON RABBITS 73 
leukocytes, degenerative changes in the renal cells (Figure 2). The adverse effects of Met in rabbits were similar to those shown in kidney of rats when exposed to Met for 20 and 30 days (El-Demerdash et al., 2013).

\section{Carcass traits}

Results of carcass traits studied are shown in Table 6. Data indicate that exposure to Met administration in diet with or without injection of ESe did not significantly affect most of carcass traits studied, except for heart, spleen, lung and fore limb percentages, which were significantly $(\mathrm{P} \leq 0.05)$ differed. The percentages of heart and lung for the rabbits of the control group were intermediate among the other percentages. The higher percentage of spleen $(0.14 \%)$ was found in the rabbits treated with $20 \mathrm{mg} \mathrm{Met} \mathrm{kg}^{-1}$ and ESe. The highest percentage $(20.88 \%)$ of fore limb of the carcass was obtained in rabbits treated with $20 \mathrm{mg}$ of Met, while the lowest one $(17.83 \%)$ was observed in rabbits treated with $10 \mathrm{mg}$ of Met with ESe. The differences among control, group of rabbits received $20 \mathrm{mg}$ Met, and that received $10 \mathrm{mg}$ Met with ESe were not significant.

\section{Conclusion}

Growth performance of all treated groups of rabbits did not show significant effects throughout the whole experimental periods. Rabbit groups exposed to sublethal doses of Met alone or Met with weekly $0.5 \mathrm{ml}$ of ESe injection showed markedly hematological and biochemical changes. Treated rabbits with weekly ESe injection showed low protection role that may be due to the flagging effects of sublethal doses of Met as showed in performance and carcass traits of rabbits. On the other hand, sublethal doses of Met indicate adverse effects in blood hematological and biochemical measurements with slight protection role of ESe that may induce clear protection with a relatively high Met doses for NZW growing male rabbits.

\section{REFERENCES}

Abd El-Maksoud, H.M. 1998. Pollution as a main factor affecting on the rabbit production. Ph.D. thesis, Faculty of Agriculture, Zagazig University, Egypt PP, 106.

Anjana, C.S., and R.N. Goswami, 2012. Selection indices for improving body weight in New Zealand White breed of rabbit maintained at the hilly Indian state of Meghalaya. $10^{\text {th }}$ World Rabbit Congress, September 3-6, Sharm El-Sheikh, Egypt 25-29. 
DIETARY EXPOSURE EFFECT OF SUBLETHAL DOSES OF METHOMYL ON RABBITS 75 
DIETARY EXPOSURE EFFECT OF SUBLETHAL DOSES OF METHOMYL ON RABBITS 77

Baron, R.L. 1991. Carbamate Insecticides. In: Hayes, W.J., Laws, R.L. (Eds.), Handbook of Pesticide Toxicology. Academic Press, New York, pp. 11251189.

Bioshop, M.L.; J. L. Duben-Engelkirk and E.P. Fody, 2000. Clinical Chemistry Principles, Procedures, Correlations. Lippincott Williams \& Wilkins. A Wolters Klower company. Philadelphia, Battimore. New York. London. Buenos Aires. Hong Kong. Sydney. Tokyo.

Carleton, R.A., B. Druy, and E.A. Wallington, 1980. Histological Technique for normal Pathological Tissues and Identification of Parasites. 5th Edi. Oxford Univ. Press, New York, USA.

Dalle Zotte, A., and Z.S. Szendro, 2011. The role of rabbit meat as functional food, a review. Meat Science, 88: 319-331.

Duncan, D.B. 1955. Multiple range and multiple F-tests. Biometrics, 11: 1-42.

Ebeid, T., H. Zeweil, M. Basyony, and H. Badry, 2012. The impact of incorporation of organic selenium into meat on growth performance, antioxidative status and immune response in growing rabbits. $10^{\text {th }}$ World Rabbit Congress, September 3-6, Sharm El-Sheikh, Egypt, 861- 864.

Ebeid, T., H. Zeweil, M. Basyony, W.M. Dosoky,and H. Badry, 2013. Fortification of rabbit diets with vitamin $\mathrm{E}$ or selenium affects growth performance, lipid peroxidation, oxidative status and immune response in growing rabbits. Livestock Science, 155: 323-331.

El-Demerdash, F.M. and H. M. Nasr, 2014. Antioxidant effect of selenium on lipid peroxidation, hyperlipidemia and biochemical parameters in rats exposed to diazinon. Journal of Trace Elements in Medicine and Biology, 28(1): 89-93.

El-Demerdash, F.M, Y. Dewer, R.H. El-Mazoudy,and A.A. Attia, 2013. Kidney antioxidant status, biochemical parameters and histopathological changes induced by methomyl in CD-1 mice. Experimental and Toxicologic Pathology, 65(6): 897-901.

El-Sheikh, E.A., A.A. Romeh, M.A. Salama,and M. B.A. Ashour, 2008. Toxicological effects and chromosomal aberration induced by diazinon in albino rats Rattus norvegicus. Proc $5^{\text {th }}$ International Conference on Biological Sciences , 5: 187-193.

El-Shenawy, N.S., R.A. Al-Eisa, F. El-Salmy,and O. Salah, 2009. Prophylactic effect of vitamin E against hepatotoxicity, nephrotoxicity, hematological induces and histopathology induced by diazinon insecticide in mice. Current Zoology,55(3): 219-226. 
Fayez, V., and M.R.E. Bahig, 1991. Short-term toxicity of methomyl in rats. Chemosphere, 23 (3): 375-381.

Fukuto, T.R. 1990. Mechanism of action of organophosphorus and carbamate insecticides. Environmental Health Perspectives, 87: 245-254.

Garba, U.S., A.A. Nasiru, M.A. Haruna, A.A. Mayun,M.B. Alhaji, W.C. Haruna, Z.A. Umar,and T.Y. Samuel, 2013. Biochemical and histopathologic changes in liver of albino rats exposed to $1 \%$ dichlorvos pesticide at sub-acute period. Journal of Pharmaceutical and Biomedical Sciences, 3(2): 1-6.

Garg, D.P., A.K. Bansal, A. Malhotra, R. Kiran,and D.K. Dhawan, 2009. Methomyl induced hematological and biochemical alterations - protection by vitamin E. Pesticide Biochemistry and Physiology, 93: 127-132.

Guanggang, X., L. Diqiu, Y. Jianzhong, G. Jingmin, Z. Huifeng, S. Mingan, T. Liming, 2013. Carbamate insecticide methomyl confers cytotoxicity through DNAdamage induction. Food and Chemical Toxicology, 53: 352358.

Harber, C. 1979. Wernicke's encephalopathy: A more common disease than realized. A neuropathological study of 51 cases. Journal of Neurology, Neurosurgery and Psychiatry, 42 (3): 226-231.

Hepler, O.E. 1966. Manual of Clinical Laboratory Method. Spring-field, IL, Thomas.

Jain, S.K. 1988. Evidence for membrane lipid peroxidation during the in vivo aging of human erythrocytes.Biochimica et Biophysica Acta ,937: 205210.

Khan, D.A., M.M. Bhatti, F.A. Khan, S.T. Naqvi, and A. Karam, 2008. Adverse effects of pesticides residues on biochemical markers in Pakistani tobacco farmers. InternationalJournal of Clinical Experimental Medicine, 1(3): 274-282.

Khan, M.Z., R. Tabssum,and S.N.H. Naqvi, 2003. Effect of cypermethrin and permethrin on cholinesterase and activity and protein contents in Rana tigerina (Amphibia). Turkish Journal of Zoology, 27: 243-246.

Koller, A. 1984. Total serum protein. Kaplin A. et al. Cli. Cem. The C.V. Mosby Co. St. Louis Toronto, Princeton, 1316-1324

Lebas, F. (2000). Vitamins in rabbit nutrition: Literature review and recommendations. World Rabbit Science, 8(4): 185 - 192.

Lukefahr, S.D., Van Vleek, L.D., Roberts, J.D. (1992). Estimates of components of variance andcovariance of carcass traits in rabbits using animal model. Journal of Applied Rabbit Research, 15: 259-273. 
DIETARY EXPOSURE EFFECT OF SUBLETHAL DOSES OF METHOMYL ON RABBITS 79

Mahrose, Kh. M., U.M. Abd El-Monem,and S.I. Peris, 2010. Effects of photoperiod and mating or semen collection times on the performance of does and bucks of New Zealand White rabbits under hot climatic conditions of Egypt. The $6^{\text {th }}$ International Conference on Rabbit Production in Hot Climate, Assuit, Egypt, pp:503-520.

Marai, I.F.M., A.A. Habeeb, A.E. Gad and Kh.M. Mahrose, 2010.Rabbits productive, reproductive and physiological traits as affected by drinking saline water: a review. The $6^{\text {th }}$ International Conference on Rabbit Production in Hot Climate, Assuit, Egypt, pp:177-189.

Mohammad, F.k., A.S. Alias, G.A.M. Faris, and B.K.h. Baggaou, 2007. Application of an electrometric method for measurement of blood cholinesterase activity in sheep, goats and cattle treated with organophosphate dyes. Journal of veterinary medicine A Physiology, pathology, clinical medicine, 54(3): 140-143.

Mossa, A.H., and M.A. Abbassy, 2012. Adverse hematological and biochemical effects of certain formulated insecticides in male rats. Research Journal of Environmental Toxicology, 6 (4): 160-168.

Mossa, A.T.H., A.A. Refaie, and A. Ramadan, 2011. Effect of exposure to mixture of four organophosphate insecticides at no observed adverse effect level dose on rat liver: The protective role of vitamin C. Research Journal of Environmental Toxicology, 5: 323-335.

National Research Council, 1977. Nutrient Requirements of Rabbits, $2^{\text {nd }}$ Revised Edition, Washington, DC: The National Academies Press 12141223.

Raja, M., A. Al-Fatah, M. Ali, M. Afzal, R.A. Hassan, M. Menon, and M.S. Dhami, 1992. Modification of liver and serum enzymes by paraquat treatment in rabbits. Drug Metabolism and Drug Interactions, 10(4): 279291.

Rooke, J.A., J.J. Robinson, and J.R. Arthur 2004. Effects of vitamin E and selenium on the performance and immune status of ewes and lambs, a review. The Journal of Agricultural Science, 142(3): 253-262.

SAS 1998. SAS Procedure Guide. Release 6.03 Edition. SAS Institute Inc., Cary NC, USA.

Shalaby, M.A., H.Y. El Zorba, R.M. Ziada, 2010.Reproductive toxicity of methomyl insecticide in male rats and protective effectof folic acid. Food and Chemical Toxicology, 48: 3221-3226.

Snedcor, G.W., and W.G. Cochran, 1982. Statistical Methods. $6^{\text {th }}$ ed. Iowa state University press, Ames, USA. 
Suraï, P.F. 2002. Selenium in poultry nutrition 2. Reproduction, egg and meat quality and practical applications. World's Poultry Science Journal, 58: 431-450.

Tanner G.A. 2012. Kidney Function. In: Bell RARaDR, editor. Medical Physiology. 4ed: Wolters Kluwer health/ Lippincott Williams \& Wilkins. pp. 399-426.

WHO 1996. Methomyl. Environmental Health Criteria 178. WHO, Geneva, p. 74.

Wintrobe, M.M., 1965. Clinical Hematology. Lea and Febiger, Philadelphia. 